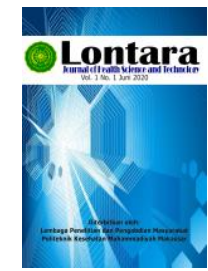

Lontara

Journal of Health Science and Technology

http://jurnal.poltekkesmu.online/lontarariset

Vol 2, No. 2, Desember 2021, pp 82-88

p-ISSN:0000-0000 dan e-ISSN: 2721-6179

DOI: https://doi.org/10.53861/lontarariset.v2i2

\title{
PEMERIKSAAN KADAR ZAT ORGANIK DALAM AIR MINUM ISI ULANG JENIS RO (REVERSE OSMOSIS)
}

\author{
Rahmawati, Dewi Arisanti, Nurhidayat \\ Teknologi Laboratorium Medis, Politeknik Kesehatan Muhammadiyah Makassar \\ Email: rahmawatiamma60@gmail.com
}

\begin{tabular}{l}
\hline \multicolumn{1}{c}{ Artikel info } \\
\hline \\
Artikel history: \\
Received; 03-09-2021 \\
Revised: 22-10-2021 \\
Accepted; 24-11-2021 \\
\hline
\end{tabular}

Keyword:

Refill drinking water, organic substances, Spectrophotometry.

Kata Kunci:

Air minum isi ulang, zat organik, Spektrofotometri
Abstract. Gallons of refilled drinking water usually don't run out in a single use but run out in a few days or even up to 1 to 2 weeks, depending on usage, and stored at room temperature $\left(27-29{ }^{\circ} \mathrm{C}\right)$. Drinking water that is stored for a long time will allow the growth of microorganisms which are influenced by environmental factors, namely temperature conditions and oxygen supply during storage. This affects the $\mathrm{pH}$ and total organic content of drinking water. Inspection of the quality of water products according to the Regulation of the Minister of Health of the Republic of Indonesia Number 492/MENKES/PER/IV/2010, which is a maximum organic matter content of $10 \mathrm{mg} / \mathrm{L}$. According to chemical parameters, drinking water must not contain inorganic and organic substances exceeding the standard with a $\mathrm{pH}$ value between 6.5-8.5. The purpose of this study was to determine the levels of organic substances in RO (Reverse Osmosis) refill drinking water. This type of research is a laboratory experiment using purposive sampling technique. The results showed that the average organic content of refilled drinking water with a storage period of 0 days was $1.839 \mathrm{mg} / \mathrm{L}, 3$ days was $2.57 \mathrm{mg} / \mathrm{L}$, and 6 days was $5.28 \mathrm{mg} / \mathrm{L}$. Thus, the levels of organic substances in drinking water are based on storage time of 0,3 , and 6 days using the spectrophotometric method according to the maximum drinking water quality standard.

Abstrak. Galon air minum isi ulang biasanya tidak habis dalam sekali pakai, tetapi habis dalam beberapa hari atau bahkan hingga 1 sampai 2 minggu, tergantung pemakaian, dan disimpan pada suhu kamar (27$29^{\circ} \mathrm{C}$ ). Air minum yang disimpan dalam waktu lama akan memungkinkan tumbuhnya mikroorganisme yang dipengaruhi oleh faktor lingkungan yaitu kondisi suhu dan suplai oksigen selama penyimpanan. Hal ini mempengaruhi $\mathrm{pH}$ dan kandungan organik total air minum. Pemeriksaan mutu produk air menurut Peraturan Menteri Kesehatan Republik Indonesia Nomor 492/MENKES/PER/IV/2010, yaitu maksimal kadar zat organik sebesar $10 \mathrm{mg} / \mathrm{L}$. Sesuai parameter kimiawi, air minum tidak boleh mengandung zat-zat anorganik dan organik melebihi standar dengan nilai $\mathrm{pH}$ antara 6,5-8,5. Tujuan dari penelitian ini adalah untuk menentukan kadar zat oeganik dalam air minum isi ulang jenis RO (Reverse Osmosis). Jenis penelitian bersifat eksperimen laboratorium menggunakan teknik pengambilan sampel secara purposive sampling. Hasil penelitian menunjukkan bahwa rata- 
rata kadar zat organik air minum isi ulang dengan lama penyimpanan 0 hari sebesar $1,839 \mathrm{mg} / \mathrm{L}, 3$ hari sebesar $2,57 \mathrm{mg} / \mathrm{L}$, dan 6 hari sebesar 5,28 mg/L. Dengan demikian bahwa kadar zat organik dalam air minum berdasarkan lama penyimpanan 0,3 , dan 6 hari dengan metode spektrofotometri sesuai standar kualitas air minum maksimum.

Coresponden author:

Email: rahmawatiamma60@gmail.com

artikel dengan akses terbuka dibawah lisensi CC BY -4.0

\section{PENDAHULUAN}

Pengadaan air bersih untuk kepentingan rumah tangga seperti untuk air minum, air mandi dan sebagainya harus memenuhi persyaratan yang sudah ditentukan oleh pemerintah Republik Indonesia. Dalam hal ini persyaratan kualitas air minum harus sesuai dengan ketentuan yang tercantum dalam Keputusan Menteri Kesehatan RI No. 907/MENKES/VII/2002, dimana setiap komponen yang terkandung dalam air minum harus sesuai dengan yang ditetapkan. Air minum selain merupakan kebutuhan esensial, namun juga berpotensi sebagai media penularan penyakit, keracunan dan sebagainya (Nuraini, 2015).

Kekurangan air yang disediakan oleh pemerintah, kebutuhan air minum yang tinggi, dan masalah air memunculkan ide untuk memproduksi air minum dalam kemasan (AMDK). Dengan harga air minum dalam kemasan yang terus naik, maka kebutuhan air minum pun terus meningkat. Sekitar tahun 1999, air minum isi ulang (AMIU) mulai menjamur di Indonesia. Harga produksinya bahkan seperempat dari harga air minum dalam kemasan. Seiring dengan perubahan kebutuhan masyarakat akan air minum yang berkualitas dan aman, keberadaan penampungan air minum infill terus meningkat. Meski lebih murah, tidak semua tangki air minum pelengkap bisa menjamin kualitas dan keamanan produknya.

Depot Air Minum Isi Ulang (DAMIU) memperoduksi juga air minum isi ulang dengan berbagai proses pengolahan salah satunya yaitu reversed osmosis (RO) dengan harga yang lebih mahal bahkan dua kali lipat dibanding air minum isi ulang biasa, sehingga perlu untuk melakukan pemeriksaan terhadap mutu produk air. Penelitian yang telah dilakukan oleh Latif (2012) menunjukkan bahwa kualitas air minum berdasarkan parameter fisik (TDS) pada air minum yang melalui proses reversed osmosis (RO) telah baik dan memenuhi standar kesehatan dengan hasil nilai TDS maksimal dari 2 sampel air minum adalah $119 \mathrm{mg} / \mathrm{L}$, tidak melebihi ambang batas yang ditetapkan Permenkes RI nomor 492 tahun 2010 adalah 500 mg/L.

Menurut Peraturan Menteri Kesehatan Republik Indonesia (Permenkes RI No. 492/MENKES/PER/IV/2010), pemeriksaan mutu produk perairan dilakukan untuk memastikan air yang dihasilkan memenuhi persyaratan kualitas air minum. yang meliputi parameter fisik, kimia, 
bakteriologis dan radiologis. Menurut parameter kimia, air minum tidak boleh mengandung zat anorganik dan organik yang melebihi standar yang ditetapkan, dan nilai $\mathrm{pH}$ antara 6,5 sampai 8,5. Zat anorganik antara lain arsenik (As), kadmium (Cd), nitrit (NO2), nitrat (NO3), mangan (Mn), tembaga $(\mathrm{Cu})$, timbal $(\mathrm{Pb})$, dan berbagai logam lainnya. Sedangkan zat organik dapat berupa deterjen, alkana terklorinasi, etilen terklorinasi, hidrokarbon aromatik dan berbagai zat organik lainnya (Kemenkes RI., 2010).

Bahan organik dapat berasal dari hewan atau tumbuhan yang bahan utamanya adalah karbon, protein dan lemak. Zat organik ini mudah terurai oleh bakteri yang menggunakan oksigen terlarut. Adanya bahan organik dalam air minum menunjukkan bahwa air minum tersebut telah tercemar oleh manusia, hewan atau sumber lainnya. Bahan organik merupakan makanan bagi bakteri atau mikroorganisme lainnya. Semakin tinggi kandungan organik di dalam air, semakin jelas air terjadinya pencemaran terhadap air tersebut (Haitami, 2016).

Satu galon air minum isi ulang biasanya tidak habis dalam sekali pakai, tetapi dalam beberapa hari atau bahkan hingga 12 minggu, tergantung pemakaian, disimpan pada suhu kamar $\left(27-29^{\circ} \mathrm{C}\right)$ atau di lemari es $\left(5^{\circ} \mathrm{C}\right)$. Air minum yang disimpan dalam waktu lama akan memungkinkan tumbuhnya mikroorganisme yang dipengaruhi oleh faktor lingkungan yaitu kondisi suhu dan suplai oksigen selama penyimpanan. Hal ini akan mempengaruhi $\mathrm{pH}$ dan kandungan organik total air minum. Waktu penyimpanan yang lebih lama akan mendorong pertumbuhan mikroorganisme dan meningkatkan kandungan zat organik yang dapat menyebabkan bau, perubahan rasa dan gangguan kesehatan (Ana H., 2010).

Penelitian yang dilakukan oleh Adelina dkk., (2011) tentang penilaian air minum isi ulang berdasarkan parameter fisika dan kimia, dari 139 sampel air minum isi ulang yang berasal dari 139 depot air minum isi ulang diperoleh nilai pH berkisar antara 5,38-8,50. Sebanyak 106 sampel (76,3\%) dinyatakan memenuhi persyaratan $\mathrm{pH}$ dan sebanyak 33 sampel $(23,7 \%)$ dinyatakan tidak memenuhi syarat $\mathrm{pH}$ karena dibawah $\mathrm{pH}$ 6,5. Sedangkan untuk zat organik dari 139 sampel tersebut diperoleh zat organik yang berada pada rentang $0,14-9,36 \mathrm{mg} / \mathrm{L}$ sehingga masih memenuhi persyaratan yang telah ditetapkan yaitu maksimal sebesar 10 mg/L (sesuai PERMENKES RI No. 492 Tahun 2010). Adanya zat organik dalam air dapat diketahui dengan menentukan angka permanganatnya. Walaupun KMnO4 sebagai oksidator yang dipakai tidak dapat mengoksidasi semua zat organik yang ada, namun cara ini sangat praktis dan cepat pengerjaannya. Standar kandungan bahan organik dalam air minum menurut Permenkes 416 Tahun 1990 dan Permenkes No 492 Tahun 2010 jumlah maksimum yang diperbolehkan adalah $10 \mathrm{mg} / \mathrm{L}$. Kemungkinan efek kesehatan dari standar deviasi adalah munculnya bau yang tidak menyenangkan dalam air minum dan dapat menyebabkan sakit perut.

Berdasarkan uraian latar belakang diatas, penulis melakukan penelitian tentang pemeriksaan parameter kimia zat organik dalam air minum isi ulang jenis RO, sesuai dengan persyaratan yang telah ditetapkan di dalam air minum menurut Permenkes. 


\section{BAHAN DAN METODE}

Jenis penelitian adalah eksperimen dengan metode deskriptif yang dilakukan pada Laboratorium Kimia dan Toksikologi Klinik Politeknik Kesehatan Muhammadiyah Makassar.

Populasi yang digunakan adalah semua depot air minum isi ulang, sedangkan sampel yang digunakan dalam penelitian ini adalah air minum isi ulang jenis RO. Teknik pengambilan sampel dalam penelitian ini adalah purposive sampling yaitu berdasarkan kriteria bahwa lama penyimpanan air minum isi ulang selama 0,3 , dan 6 hari.

\section{HASIL PENELITIAN}

Konsentrasi kalium permanganat dalam air minum ditentukan dengan spektrofotometri. Prinsip operasinya adalah ketika cahaya dipancarkan ke sampel, sebagian diserap dan sebagian ditransmisikan. Larutan standar kalium permanganat dengan spektrofotometer UV-tampak pada panjang gelombang $525 \mathrm{~nm}$ yang diperoleh hasil seperti pada tabel 1 sebagai berikut:

Tabel 1. Data Hasil Pemeriksaan Larutan Standar $\mathrm{KMnO}_{4}$ dengan Metode Spektrofotometri

\begin{tabular}{ccc}
\hline No. & Konsentrasi Larutan Standar $\mathbf{K M n O}_{\mathbf{4}}(\mathbf{p p m})$ & Absorban \\
\hline $\mathbf{1 .}$ & 2,50 & 0,061 \\
\hline $\mathbf{2 .}$ & 5,00 & 0,062 \\
\hline $\mathbf{3 .}$ & 7,50 & 0,063 \\
\hline $\mathbf{4 .}$ & 10,0 & 0,141 \\
\hline $\mathbf{5 .}$ & 12,5 & 0,162 \\
\hline
\end{tabular}

Larutan deret standar kalium permanganat dibuat dari konsentrasi 2,5 mg/L sampai dengan 12,5 mg/L. Berdasarkan tabel 1 menunjukkan bahwa telah diperoleh nilai absorban dari masingmasing larutan standar. Nilai absorbansi digunakan untuk menggambar kurva kalibrasi sehingga dapat diketahui persamaan regresi liniernya. Pembuatan larutan deret standar digunakan untuk membuat kurva kalibrasi, sehingga diperoleh persamaan kurva kalibrasi yang digunakan untuk menentukan kandungan kalium permanganat. Persamaan regresi linier yang dihasilkan adalah $\mathrm{y}=0,0112 \mathrm{x}+$ 0,0135. Persamaan ini digunakan untuk menghitung konsentrasi masing-masing dari 10 sampel air minum dengan nilai absorbansi (y) yang diketahui, sampel ini berasal dari pengukuran spektrofotometer UV-Vis.

Pemeriksaan bahan organik dalam sampel air minum dengan lama penyimpanan 0, 3, dan 6 hari menggunakan metode spektrofotometri menghasilkan nilai absorbansi yang dapat dilihat pada tabel 2 sebagai berikut: 
Tabel 2. Data Hasil Pemeriksaan Zat Organik pada Air Minum Isi Ulang dengan Metode Spektrofotometri

\begin{tabular}{ccccc}
\hline No & Sampel & $\begin{array}{c}\text { 0 hari } \\
\text { (Absorban) }\end{array}$ & $\begin{array}{c}\text { 3 hari } \\
\text { (Absorban) }\end{array}$ & $\begin{array}{c}\text { 6 hari } \\
\text { (Absorban) }\end{array}$ \\
\hline $\mathbf{1 .}$ & A & 0,061 & 0,038 & 0,035 \\
\hline $\mathbf{2 .}$ & B & 0,056 & 0,040 & 0,033 \\
\hline $\mathbf{3 .}$ & C & 0,055 & 0,047 & 0,033 \\
\hline $\mathbf{4 .}$ & D & 0,063 & 0,046 & 0,030 \\
\hline $\mathbf{5 .}$ & E & 0,046 & 0,045 & 0,032 \\
\hline $\mathbf{6 .}$ & F & 0,082 & 0,046 & 0,037 \\
\hline $\mathbf{7 .}$ & G & 0,087 & 0,040 & 0,035 \\
\hline $\mathbf{8 .}$ & H & 0,106 & 0,040 & 0,036 \\
\hline $\mathbf{9 .}$ & I & 0,088 & 0,042 & 0,035 \\
\hline $\mathbf{1 0 .}$ & J & 0,087 & 0,041 & 0,039 \\
\hline
\end{tabular}

Kadar permanganat diperoleh dengan memasukkan nilai absorbansi sampel ke dalam persamaan regresi linier, dan kadar kalium permanganat diperoleh dalam $\mathrm{mg} / \mathrm{L}$ yang ditunjukkan pada tabel 3 berikut:

Tabel 3. Data Hasil Perhitungan Kadar Zat Organik pada Air Minum Isi Ulang dengan Metode Spektrofotometri

\begin{tabular}{ccccc}
\hline No & Sampel & $\begin{array}{c}\mathbf{0} \text { hari } \\
(\mathbf{m g} / \mathbf{L})\end{array}$ & $\begin{array}{c}\mathbf{3} \text { hari } \\
(\mathbf{m g} / \mathbf{L})\end{array}$ & $\begin{array}{c}\mathbf{6} \text { hari } \\
(\mathbf{m g} / \mathbf{L})\end{array}$ \\
\hline $\mathbf{1 .}$ & $\mathrm{A}$ & 1,90 & 2,1 & 4,2 \\
\hline $\mathbf{2 .}$ & $\mathrm{B}$ & 1,70 & 2,3 & 3,7 \\
\hline $\mathbf{3 .}$ & $\mathrm{C}$ & 1,70 & 2,9 & 3,7 \\
\hline $\mathbf{4 .}$ & $\mathrm{D}$ & 1,40 & 2,9 & 4,4 \\
\hline $\mathbf{5 .}$ & $\mathrm{E}$ & 1,60 & 2,8 & 2,9 \\
\hline $\mathbf{6 .}$ & $\mathrm{F}$ & 2,09 & 2,9 & 6,1 \\
\hline $\mathbf{7 .}$ & $\mathrm{G}$ & 1,90 & 2,3 & 6,5 \\
\hline $\mathbf{8 .}$ & $\mathrm{H}$ & 2,00 & 2,3 & 8,2 \\
\hline $\mathbf{9 .}$ & $\mathrm{I}$ & 1,90 & 2,5 & 6,5 \\
\hline $\mathbf{1 0}$ & J & 2,20 & 2,7 & 6,6 \\
\hline
\end{tabular}

Berdasarkan tabel 3, menunjukkan hasil bahwa penetapan kadar zat organik dengan metode spektrofotometri diperoleh hasil yang memenuhi syarat sesuai dengan Peraturan Menteri Kesehatan RI No.492/MENKES/PER/IV/2010, yaitu kadar zat organik sebagai angka permanganat kurang dari 10 $\mathrm{mg} / \mathrm{L}$.

\section{PEMBAHASAN}

Penelitian ini dilakukan untuk menentukan kadar zat organik dalam air minum isi ulang yang diperoleh dari 10 depot air minum di lokasi Kecamatan Manggala Kota Makassar. Penetapan kadar zat organik dalam sampel air dilakukan dengan menggunakan metode spektrofotometri.

Hasil pemeriksaan rata-rata kadar zat organik air minum isi ulang yang diuji menggunakan metode spektrofotometri dengan lama penyimpanan 0 hari sebesar $1,839 \mathrm{mg} / \mathrm{L}, 3$ hari sebesar 2,57 $\mathrm{mg} / \mathrm{L}$, dan 6 hari sebesar 5,28 mg/L. Rata-rata kandungan bahan organik pada air minum isi ulang 
dengan masa simpan 6 hari lebih tinggi dibandingkan rata-rata kandungan bahan organik pada air minum dengan masa simpan 0 dan 3 hari. Setelah 3 hari penyimpanan, kandungan organik rata-rata meningkat dibandingkan dengan 0 hari penyimpanan. Berdasarkan hasil yang diperoleh diketahui bahwa semakin lama waktu penyimpanan maka semakin tinggi kandungan bahan organik pada air minum isi ulang. Hal ini dimungkinkan karena terbuka saat air minum dituangkan ke dalam labu erlenmeyer untuk pengujian, sehingga dapat terjadi kontaminasi bahan organik lebih lanjut.

Air minum umumnya tidak digunakan sekali, tetapi habis dalam beberapa hari. Semakin lama waktu penyimpanan, pertumbuhan mikroorganisme, mikroorganisme tersebut akan menjadi bakteri patogen dan menyebabkan peningkatan kandungan organik. Peningkatan bahan organik dalam air minum dapat dipengaruhi oleh perkembangbiakan mikroorganisme dan kesalahan pengambilan sampel oleh peneliti, peneliti tidak mengambil sampel yang steril dan wadah yang digunakan untuk pengambilan sampel tidak sehat dan steril, yang mempengaruhi dan meningkatkan kadar bahan organik. Setelah 3 dan 6 hari penyimpanan, kandungan bahan organik dalam air minum tambahan meningkat. Hal ini dimungkinkan karena mikroorganisme yang ada tidak dapat mengoksidasi semua zat organik dalam air minum, sehingga setelah penyimpanan 3 dan 6 hari relatif tinggi dibandingkan dengan hari ke- 0 .

Sumber air baku yang digunakan secara alami telah mengandung zat organik. Air baku pada pengolahan depot air minum isi ulang berasal dari PDAM. Menurut Thedy Susanto (2010), air olahan PDAM memiliki kualitas yang kurang baik yang dapat disebabkan karena kualitas air baku yang buruk, operasional dan maintenance yang kurang baik serta kerusakan pipa jaringan PDAM (Susanto, T., 2010). Kemudian ditegaskan pada hasil penelitian Tri Tugaswati (1987) penyimpangan kadar Zat Organik dalam air minum diperkirakan akibat kontaminasi lingkungan pada jaringan pipa distribusi PDAM.

Bahan baku utama yang digunakan berasal dari sumber air dengan kualitas yang terjamin, sehingga beberapa hal yang harus dilakukan untuk menjamin kualitas air baku, yaitu air baku harus dilindungi dari pencemaran kimia dan mikroba yang merugikan atau merugikan kesehatan. Selain itu, pemeriksaan sensorik (bau, rasa, warna), fisik, kimia, dan mikrobiologi air baku diperiksa secara berkala (Kemenperindag, 2004).

\section{KESIMPULAN}

Berdasarkan penelitian yang telah dilakukan maka dapat disimpulkan bahwa:

1. Rata-rata kadar zat organik dalam air minum isi ulang dengan metode spektrofotometri dengan lama penyimpanan 0 hari sebesar 1,839 mg/L, 3 hari sebesar $2,57 \mathrm{mg} / \mathrm{L}$, dan 6 hari sebesar 5,28 $\mathrm{mg} / \mathrm{L}$. 
2. Kadar zat organik dalam air minum dengan metode spektrofotometri berdasarkan lama penyimpanan 0,3 , dan 6 hari memenuhi standar kualitas air minum menurut kadar maksimum yang ditetapkan oleh KEMENKES RI No.492/MENKES/SK/VI/2010 yaitu sebesar 10 mg/L.

\section{SARAN}

Peneliti menyarankan kepada peneliti selanjutnya untuk melakukan penelitian tentang uji parameter mikrobiologi terhadap sampel air minum isi ulang.

\section{UCAPAN TERIMA KASIH}

Ucapan terima kasih penulis kepada Direktur, Kaprodi D3 TLM yang telah memberikan izin penelitian, dan seluruh civitas akademika prodi TLM Politeknik Kesehatan Muhammadiyah Makassar yang telah memberikan bantuan atas seluruh rangkaian penyelesaian penelitian.

\section{DAFTAR PUSTAKA}

Adelina, R., Winarsih, Setyorini H. A., 2011. Penilaian Air Minum Isi Ulang Berdasarkan Parameter Fisika dan Kimia di dan luar Jabodetabek Tahun 2011. Jakarta: Pusat Biomedis dan Teknologi Dasar Kesehatan Badan Litbangkes Kemenkes RI.

Ana H., 2010, Pengaruh Lama Waktu Simpan pada Suhu Ruang $\left(27-29^{\circ}\right.$ C) Terhadap Kadar Zat Organik pada Air Minum Isi Ulang. Skripsi. Fakultas Ilmu Keperawatan dan Kesehatan, Universitas Muhammadiyah Semarang, Semarang.

Haitami, Rakhmia D., Fakhridani S., 2016. Ketepatan Hasil dan Variasi Waktu Pendidihan Pemeriksaan Zat Organik. Banjarmasin: Medical Laboratory Technology Journal. 2 (2): hal. 61-65.

Kementerian Perindustrian dan Perdagangan Indonesia, 2004, Peraturan Menteri Perindustrian dan Perdagangan Indonesia Nomor 651/MPP/Kep/10/2004 tentang Persyaratan Teknis Depot Air Minum, Jakarta.

Kemenkes RI. 2010. Peraturan Menteri Kesehatan Republik Indonesia Nomor 492/MENKES/PER/IV/ 2010 Tentang Persyaratan Kualitas Air Minum. Jakarta.

Latif. I., W., 2012, Studi Kualitas Air Minum Isi Ulang Ditinjau Dari Proses Ozonisasi, Ultraviolet, Dan Reversed Osmosis Di Kecamatan Kota Tengah Dan Kecamatan Kota Selatan Kota Gorontalo, Skripsi, Jurusan Kesehatan Masyarakat, Fakultas Ilmu-Ilmu Kesehatan dan Keolahragaan, Universitas Negeri Gorontalo (UNG). Gorontalo.

Nuraini, Iqbal, Sabhan. 2015. Analisis Logam Berat dalam Air Minum Isi Ulang (AMIU) dengan Menggunakan Spektofotometri Serapan Atom (SSA). Gravitas. 14 (1): 37-39.

Susanto, T., 2010. Pegolahan Air PDAM Surabaya Menjadi Air Siap Minum Menggunakan GAC, Filter Pasir Silica, dan UV. Teknik Lingkungan, Institut Teknologi Sepuluh Nopember (ITS). Surabaya. 